\title{
Relationship between understanding of COVID-19's infographics and the efforts to prevent COVID-19 transmission
}

\author{
Rahmat Bakhtiar, ${ }^{1 *} \mathrm{Hilda}_{,}{ }^{2}$ Krispinus Duma, ${ }^{1}$ and Riries Choiru Pramulia Yudia ${ }^{1}$ \\ ${ }^{1}$ Department of Public Health, Faculty of Medicine, Universitas Mulawarman, Samarinda, Indonesia \\ ${ }^{2}$ Department of Nursing, East Kalimantan Health Polytechnic of the Ministry of Health, Samarinda, Indonesia
}

SUBMITTED: 9 June 2020

REVISED: 12 July 2020

ACCEPTED: 15 July 2020

\section{KEYWORDS}

COVID-19 infographic

Social distancing

Washing hands

Wearing a mask

Body's immune

system

Pandemic
ABSTRACT The prevention of disease transmission is an effective cost-strategy in controlling COVID-19. The scenario of the control of COVID-19 in Samarinda City consists of 3 phases, namely initial, advanced, and recovery. The outcome of the advanced phase is flattening the transmission curve of the COVID-19 pandemic, with an increased proportion of patients in recovery, and an increased culture of preventing disease transmission in society. This study aimed at knowing the influence of the understanding of COVID-19 infographics on the efforts to prevent COVID-19 transmission at the advanced phase. A survey was conducted via social media from April 21st to April 30th, 2020. The preventive actions for the disease transmission as the dependent variable in this study were social distancing, wearing a mask, washing hands, and efforts to enhance the body's immunity, while the independent variable was the understanding of COVID-19 infographics updated daily. The results of the study showed that the proportion of the population who understood the infographics well was $79.5 \%$, the community participation in practicing social distancing $(81.6 \%)$, wearing a mask $(50.9 \%)$, washing hands as frequently as possible $(74.3 \%)$, and the efforts to strengthen the body's immune system $(73.6 \%)$ with a consistency level of $55.12 \%$. The lowest rate for the activity of social distancing was visiting elders or the people suffering from comorbidities with $54.71 \%$. A good understanding of infographics could increase adherence to the recommendations of social distancing. The implementation of social distancing, wearing a mask, washing hands as frequently as possible, and the efforts to improve the body's immune system need to be done consistently to prevent the COVID-19 transmission and as a result, the potential transmission could be minimized to optimize the recovery phase and anticipate the possible second wave of the COVID-19 pandemic.

(C) The Journal 2020. This article is distributed under a Creative Commons Attribution-ShareAlike 4.0 International license.

\section{Introduction}

The COVID-19 pandemic was declared as an international public health emergency and has resulted in epic global deaths and human damage. ${ }^{1,2}$ As a country with community transmission, COVID-19 in Indonesia is spreading without any detection of the source of the infection. ${ }^{3}$ The situation related to COVID-19 in Indonesia shows an increased number of cases and the flattening of the epidemic curve has not been seen yet, however, the proportion of recovery cases is increasing. ${ }^{4}$ Since the first case was identified on March $18^{\text {th }}, 2020$, the COVID-19 case numbers in East Kalimantan province have tended to increase. Currently, there are 85 cases confirmed

\footnotetext{
*Correspondence: r.bakhtiar@fk.unmul.ac.id

Departement of Public Health, Faculty of Medicine Mulawarman University, Jl. Krayan Kampus Unmul Gunung Kelua Samarinda Kalimantan Timur 75119, Indonesia
}

positive cases of COVID-19 and 448 Patients Under Investigation (PDP) dominated by the Gowa cluster transmission. ${ }^{4,5}$

The development of the COVID-19 case numbers in Samarinda City until the end of April 2020 showed that the total confirmed cases were 10 deceased patients, 25 PDP, and 1,036 Patients Under Monitoring (ODP). ${ }^{5}$ The increased rate of COVID-19 cases in Samarinda City was estimated to reach its peak at the end of May 2020.6,7 Despite the low number of cases, it is estimated to increase because Samarinda is surrounded by district areas with local transmissions, such as Kutai Kartanegara and Balikpapan, and provinces with a high number of cases, such as East Java, South Sulawesi, and South Kalimantan. Anticipating the increased incidence, the COVID-19 Task Force team in Samarinda City implemented the 3-phase mitigation strategy, namely the initial phase, 
advanced phase, and recovery phase. The strategy of the advanced phase is as follows: increasing the sensitivity towards PDP, optimizing the rapid testing, conducting both self-isolation and isolation in the quarantine facilities, applying lockdown in the local areas, preparing hospitals as a buffer of emergency healthcare, conducting a program of intensive communication with the stakeholders, and educating the community related to the preventive actions against COVID-19 transmission ${ }^{6}$.

The increased knowledge of the dynamics of COVID-19 transmission and the efforts to prevent infection with the Severe Acute Respiratory Syndrome-Coronavirus 2 (SARS-Cov2) disease are the effective methods in controlling COVID-19 transmission. ${ }^{8-11}$ The entire and massive education is conducted by using social media. ${ }^{12}$ The City Health Office along with the Public Information Management Officer of Samarinda City conducted a community outreach with social media-based health education, including WhatsApp (WA), Facebook, and Instagram, and made area mapping based on the potential risks of transmission. ${ }^{6}$ The people of Samarinda, one of the fastest-growing cities in Kalimantan, are increasingly demanding access to good quality healthcare information. Even though $98.19 \%$ of the people in Samarinda have Smartphones, only $22 \%$ of them have actively accessed the COVID-19 information from the Samarinda Health Office channels. ${ }^{13}$ This study aimed at knowing the preventive actions against disease transmission based on the education of COVID-19 infographics.

\section{Method}

The COVID-19 infographic was used by the COVID-19 control team in Samarinda city to spread the information concerning COVID-19 to the society. The information of the COVID-19 infographics consists of the risk of transmission in each region, the total number of patients confirmed positive for COVID-19, the total recovered people, PDP, ODP and the information related to the education on preventing the COVID-19 transmission. These infographics can be accessed via social media as follows: Facebook: SAMARINDASIAGA@samarindasiaga112,@ diskominfo.samarinda, @pemkot.samarinda,
Instagram: SAMARINDASIAGA112, and the COVID-19 Call Centre at \#112.

We conducted a cross-sectional study. All people in Samarinda city who actively access the COVID-19 information every day via their Smart phones, including WA/Facebook/Instagram, are the population of this study. The questionnaire was distributed by the city health officials who announced that the COVID 19 situation in Samarinda had entered an advanced phase for 3 weeks between April 10 and April 31, 2020. The percentage of people $\geq 18$ years old who actively accessed the information related to COVID-19 was $22 \%$. It means that the $p$-value was 0.02 and the q-value was 0.78 . The limit of error (d) was 0.05 . Thus, the required total sample was 242 respondents.

The questionnaire in the Google form was distributed to the society for 10 days after the COVID-19 control team declared that the situation of the COVID-19 pandemic in Samarinda City had entered an advanced phase. This study used a questionnaire that could be accessed via the following link: https://forms.gle/UzAwGaKHqzfuuUsa9. The questionnaire consisted of demographic data, understanding of COVID-19 infographics, the practice of washing hands, keeping a safe distance, wearing a mask, and strengthening the body's immune system. The researchers consulted about the constructs of the study with the experts for their professional judgment and input. The validity test was conducted with 15 respondents using the Google form with a response rate of $80 \%$. The result of the validity test to 15 questions was $0.562-0.797$. The reliability test was conducted using the internal consistency approach aiming at knowing the consistency between items or parts of the survey questionnaire. This study used Cronbach's alpha formula (Cronbach's coefficient $\alpha$ ) and it resulted in $(r)$ of 0.64 .

The independent variable in this study was the understanding of the infographics as an early warning system issued periodically by the Department of Communication and Informatics of Samarinda City. Meanwhile, the dependent variable in this study was the preventive efforts by the community consisting of practicing social distancing, washing hands, wearing a mask, and the efforts to strengthen the 
body's immune system. The understanding of the infographics was in the form of the interpretation of colors, numbers, the relevancy of information, and the respondent's interpretation toward the potential risks in each village.

The researchers used a $(1-5)$ Likert scale ranging from 1-none of the time, to 3-some of the time, and 5-all of the time. Each dependent variable was classified into two groups, namely appropriate with recommendations and not appropriate with recommendations for the preventive actions against disease transmission, by using a cut-off point in the median score. Alternatively, the researchers evaluated the consistency level toward the preventive actions against disease transmission. Even though the approval based on individual information was not required for this study, all data were handled as an unidentified dataset to protect the respondents' privacy and confidentiality. The data analysis described the respondents' characteristics based on the region at risk with univariate analysis, and bivariate analysis using a Chi-squared test $\left(\chi^{2}\right)$.

\section{Result}

The total response from a digital questionnaire sent via a link for 10 days starting from April 21 April 30, 2020, showed that the total number who responded was 242 respondents. The excluded data were as follows: 6 respondents filled out the form incompletely and 2 questionnaires were filled out by children at the age of below 18 years old so that the total respondents enrolled in this study was 234 respondents.

The Samarinda local government used

Table 1. The respondents' characteristics

\begin{tabular}{|c|c|c|c|c|c|c|c|c|}
\hline \multirow{2}{*}{\multicolumn{2}{|c|}{ Respondents' Characteristics }} & \multicolumn{4}{|c|}{ Status of Domicile $(\mathrm{N}=234)$} & \multirow[b]{2}{*}{ Total } & \multirow[b]{2}{*}{$\%$} & \multirow[b]{2}{*}{ p-value } \\
\hline & & $\begin{array}{l}\text { High } \\
\text { Risk }\end{array}$ & $\%$ & $\begin{array}{l}\text { Low } \\
\text { Risk }\end{array}$ & $\%$ & & & \\
\hline \multirow[t]{2}{*}{ Age } & $\begin{array}{l}<20 \text { y.o. } \\
20-30 \text { y.o. } \\
31-40 \text { y.o. } \\
41-50 \text { y.o. } \\
>50 \text { y.o. }\end{array}$ & $\begin{array}{l}18 \\
62 \\
26 \\
20 \\
11\end{array}$ & $\begin{array}{l}7.7 \\
26.5 \\
11.1 \\
8.5 \\
4.7\end{array}$ & $\begin{array}{l}13 \\
30 \\
30 \\
17 \\
7\end{array}$ & $\begin{array}{l}5.6 \\
12.8 \\
12.8 \\
7.3 \\
3.0\end{array}$ & $\begin{array}{l}31 \\
92 \\
56 \\
37 \\
10\end{array}$ & $\begin{array}{l}13.2 \\
39.3 \\
23.9 \\
15.8 \\
7.7\end{array}$ & 0.239 \\
\hline & \multicolumn{8}{|c|}{ Mean \pm SD score for age: $32.29 \pm 11.7$ y.o. (min:18 max:75) } \\
\hline Gender & $\begin{array}{l}\text { Male } \\
\text { Female }\end{array}$ & $\begin{array}{l}51 \\
86\end{array}$ & $\begin{array}{l}21.8 \\
36.8\end{array}$ & $\begin{array}{l}30 \\
67\end{array}$ & $\begin{array}{l}12.8 \\
28.6\end{array}$ & $\begin{array}{l}81 \\
153\end{array}$ & $\begin{array}{l}34.6 \\
65.4\end{array}$ & 0.391 \\
\hline Education & $\begin{array}{l}\text { Elementary/Junior High school or } \\
\text { equivalent } \\
\text { High School or equivalent } \\
\text { Associate Degree (D3) } \\
\text { (D4)/ Bachelor Degree (S1) } \\
\text { Master (S2)/ Ph.D. (S3) }\end{array}$ & $\begin{array}{l}2 \\
43 \\
10 \\
58 \\
24\end{array}$ & $\begin{array}{l}0.9 \\
\\
18.4 \\
4.3 \\
24.8 \\
10.3\end{array}$ & $\begin{array}{l}4 \\
24 \\
9 \\
42 \\
18\end{array}$ & $\begin{array}{l}1.7 \\
10.3 \\
3.8 \\
17.9 \\
7.7\end{array}$ & $\begin{array}{l}6 \\
67 \\
19 \\
100 \\
42\end{array}$ & $\begin{array}{l}2.6 \\
\\
28.6 \\
8.1 \\
42.7 \\
17.9\end{array}$ & 0.733 \\
\hline Occupation & $\begin{array}{l}\text { Civil Servant/honorary } \\
\text { Entrepreneur } \\
\text { Private Employee } \\
\text { University Student/Student } \\
\text { Others }\end{array}$ & $\begin{array}{l}29 \\
27 \\
14 \\
36 \\
31\end{array}$ & $\begin{array}{l}12.4 \\
11.5 \\
6.0 \\
15.4 \\
13.2\end{array}$ & $\begin{array}{l}26 \\
24 \\
6 \\
15 \\
26\end{array}$ & $\begin{array}{l}11.1 \\
10.3 \\
2.6 \\
6.4 \\
11.1\end{array}$ & $\begin{array}{l}55 \\
51 \\
20 \\
51 \\
57\end{array}$ & $\begin{array}{l}23.5 \\
21.8 \\
8.6 \\
21.8 \\
24.3\end{array}$ & 0.202 \\
\hline Ethnicity & $\begin{array}{l}\text { Javanese } \\
\text { Buginese/Makassarnese/Torajans } \\
\text { Banjarnese } \\
\text { Dayaknese } \\
\text { Others }\end{array}$ & $\begin{array}{l}66 \\
30 \\
14 \\
5 \\
22\end{array}$ & $\begin{array}{l}28.2 \\
12.8 \\
6.0 \\
2.1 \\
9.1\end{array}$ & $\begin{array}{l}48 \\
18 \\
15 \\
2 \\
14\end{array}$ & $\begin{array}{l}20.5 \\
7.7 \\
6.4 \\
0.9 \\
6.0\end{array}$ & $\begin{array}{l}104 \\
48 \\
29 \\
7 \\
36\end{array}$ & $\begin{array}{l}48.7 \\
20.5 \\
12.4 \\
3.0 \\
15.3\end{array}$ & 0.772 \\
\hline $\begin{array}{l}\text { Frequency of being } \\
\text { outside the home }\end{array}$ & $\begin{array}{l}\leq 7 \text { times/ week } \\
>7 \text { times/ week }\end{array}$ & $\begin{array}{l}86 \\
51\end{array}$ & $\begin{array}{l}36.8 \\
21.8\end{array}$ & $\begin{array}{l}55 \\
42\end{array}$ & $\begin{array}{l}23.5 \\
17.9\end{array}$ & $\begin{array}{l}141 \\
93\end{array}$ & $\begin{array}{l}70.3 \\
39.7\end{array}$ & 0.424 \\
\hline $\begin{array}{l}\text { The consistency } \\
\text { of following the } \\
\text { recommendation } \\
\text { for the COVID-19 } \\
\text { prevention }\end{array}$ & $\begin{array}{l}\text { Consistent } \\
\text { Not Consistent }\end{array}$ & $\begin{array}{l}25 \\
112\end{array}$ & $\begin{array}{l}10.6 \\
47.6\end{array}$ & $\begin{array}{l}23 \\
74\end{array}$ & $\begin{array}{l}9.9 \\
31.9\end{array}$ & $\begin{array}{l}48 \\
186\end{array}$ & $\begin{array}{l}20.5 \\
79.5\end{array}$ & 0.392 \\
\hline
\end{tabular}




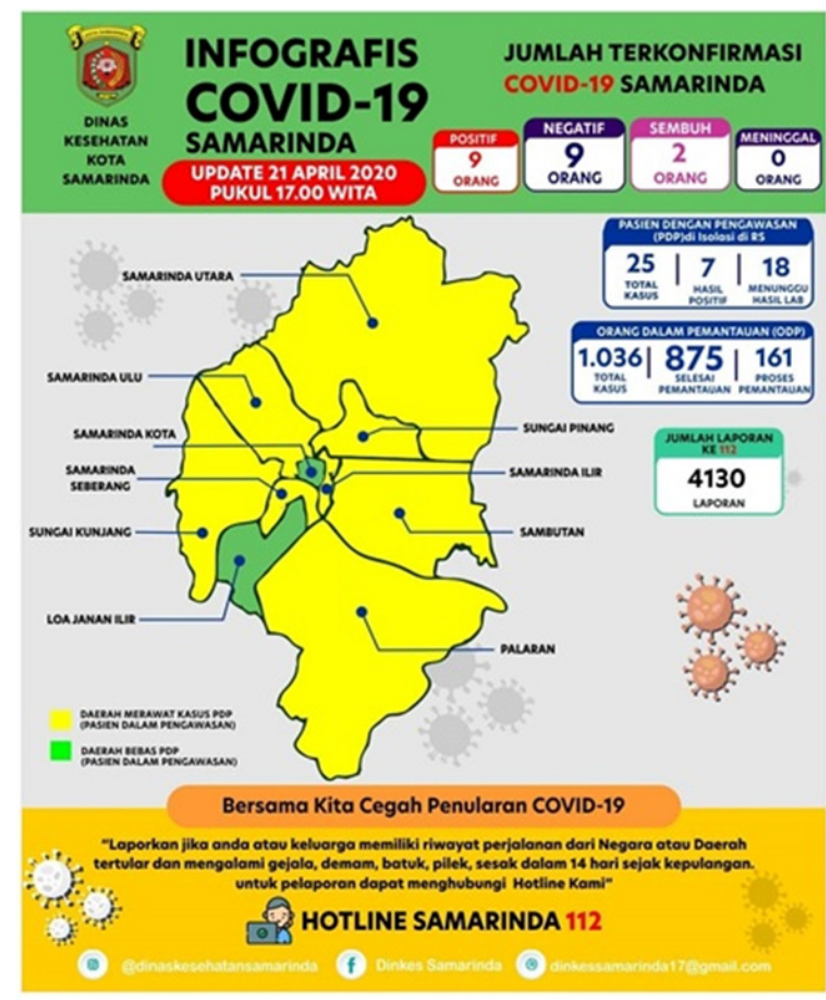

(a)

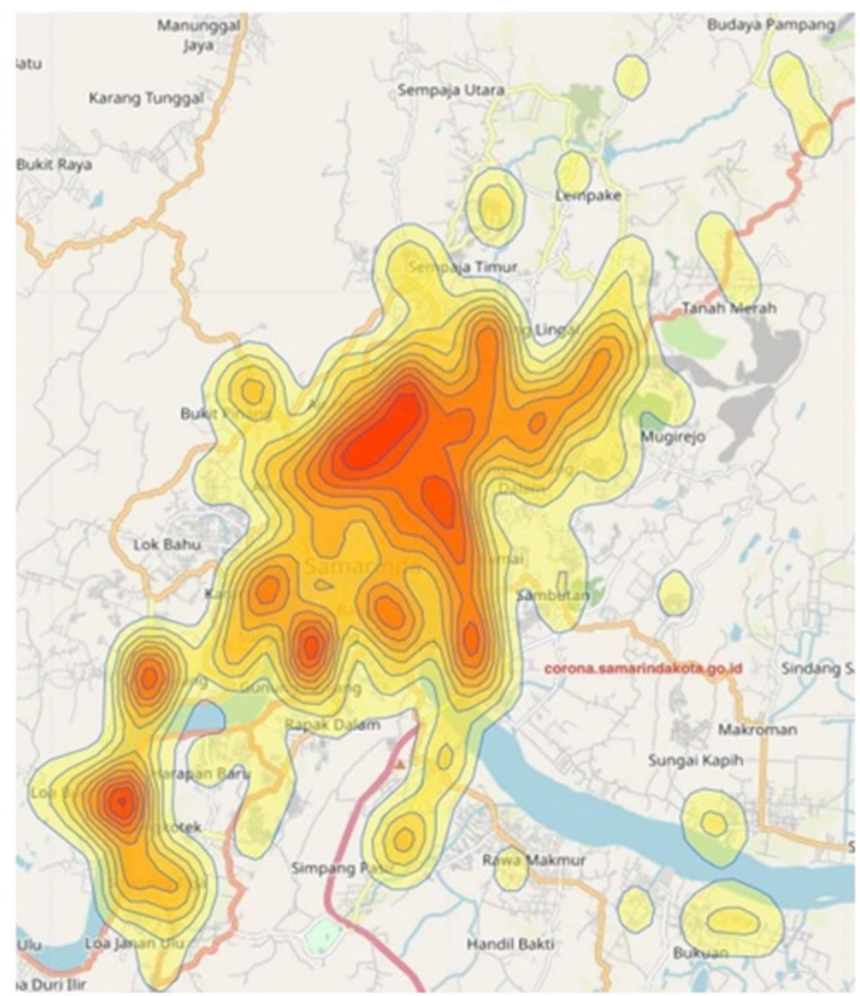

(b)

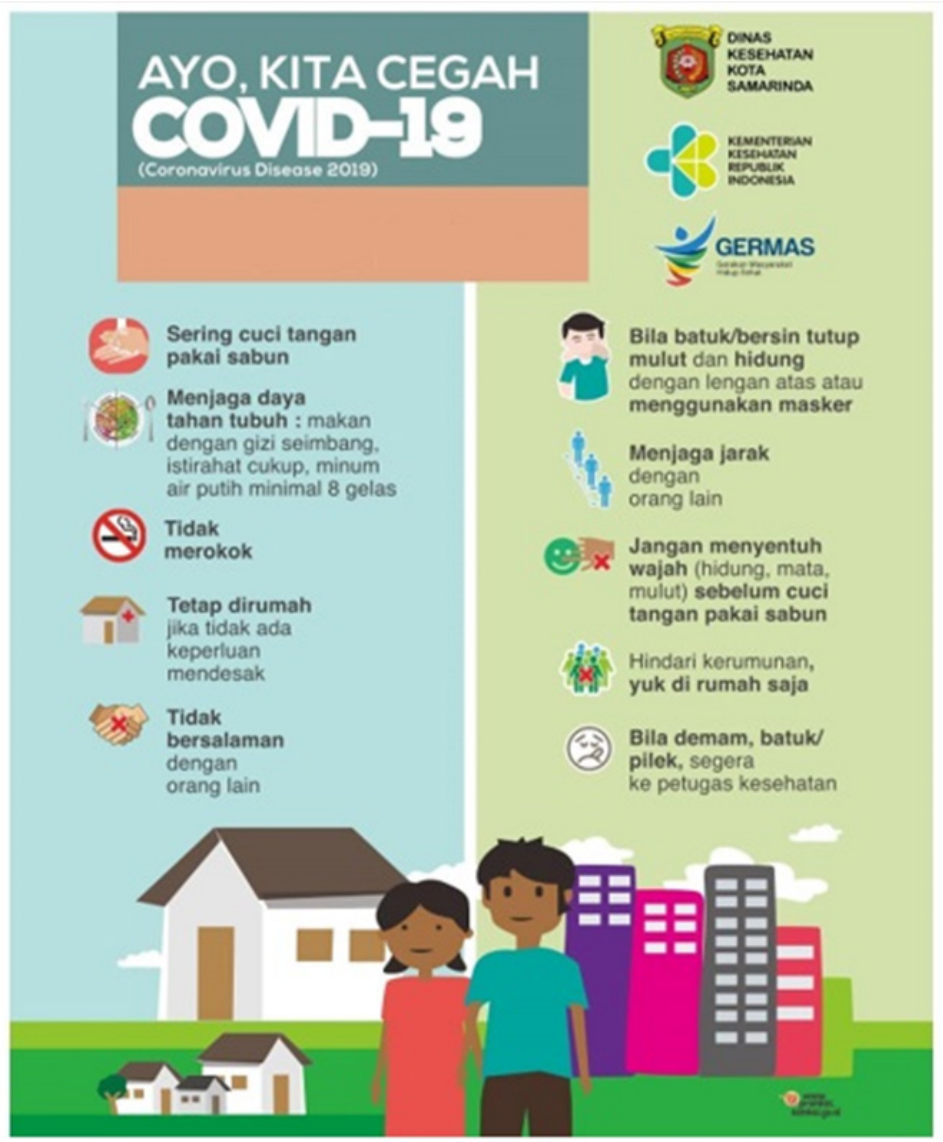

(c)

Figure 1. The COVID-19 Infographic on the Third Week of April 2020. (a) The information of daily case development. (b) The information for the region at high-risk COVID-19 transmission in Samarinda city. (c) The education on preventing COVID-19 transmission. 
Table 2. The distribution of the understanding of COVID-19 infographic during the advanced phase of COVID-19 in Samarinda City

\begin{tabular}{|c|c|c|c|c|}
\hline \multirow{2}{*}{ Variables } & \multicolumn{4}{|c|}{$(\mathrm{N}=234)$} \\
\hline & Yes & $\%$ & No & $\%$ \\
\hline The Understanding of the COVID-19 Infographic & 166 & 79.5 & 48 & 20.5 \\
\hline Complying with Social Distancing recommendation & 178 & 86.1 & 56 & 23.9 \\
\hline Complying with the recommendation of Wearing a Mask & 119 & 50.9 & 115 & 49.1 \\
\hline Complying with the recommendation of Washing Hands & 164 & 74.3 & 60 & 25.6 \\
\hline Complying with the recommendation of Strengthening the Body's Immune System & 172 & 73.6 & 66 & 26.5 \\
\hline
\end{tabular}

Table 3. The understanding of COVID-19 infographics during the advanced phase of COVID-19 in Samarinda City

\begin{tabular}{llllll}
\hline \multirow{2}{*}{ No. } & \multirow{2}{*}{ Knowledge of Infographics } & (N=234) & & & No \\
\cline { 3 - 6 } & & Yes & \% & \% \\
\hline 1. & Color Display & 204 & 87.17 & 30 & 12.83 \\
2. & Numeral Display & 168 & 71.79 & 66 & 28.21 \\
3. & The Relevancy of Information & 96 & 41.02 & 138 & 58.98 \\
4. & The Interpretation of Regions at risk & 163 & 69.65 & 71 & 30.35 \\
\hline
\end{tabular}

Table 4. The illustration of the practice of social distancing during the advanced phase of COVID-19 in Samarinda City

\begin{tabular}{|c|c|c|c|c|c|}
\hline \multirow{2}{*}{ No } & \multirow{2}{*}{ The practice of social distancing during the COVID-19 pandemic } & \multicolumn{4}{|c|}{$(\mathrm{N}=\mathbf{2 3 4})$} \\
\hline & & Yes & $\%$ & No & $\%$ \\
\hline 1. & Keeping a distance of 1.5 meters away from one another & 196 & 84.61 & 38 & 15.49 \\
\hline 2. & Avoiding crowd and unnecessary activities & 153 & 65.38 & 81 & 34.62 \\
\hline 3. & Not conducting or restricting a meeting with elders/people with comorbidity & 106 & 45.29 & 128 & 54.71 \\
\hline 4. & No shaking hands/hugging/kissing hands or cheeks when meeting other people & 220 & 94.01 & 14 & 6.99 \\
\hline 5. & Staying and working at home & 185 & 79.05 & 49 & 20.95 \\
\hline 6. & Using public transportation & 208 & 88.88 & 26 & 11.12 \\
\hline 7. & Conducting group meetings & 213 & 91.02 & 31 & 8.98 \\
\hline
\end{tabular}

Table 5. The analysis of the relation of the understanding of infographics with the efforts to prevent COVID-19 transmission

\begin{tabular}{|c|c|c|c|c|c|}
\hline \multirow[t]{2}{*}{ Independent Variables } & \multirow[t]{2}{*}{ Dependent Variables } & \multirow[t]{2}{*}{ P-Value } & \multirow[t]{2}{*}{ OR } & \multicolumn{2}{|l|}{$95 \% \mathrm{Cl}$} \\
\hline & & & & Lower & Upper \\
\hline \multirow{4}{*}{$\begin{array}{l}\text { Knowledge of } \\
\text { Infographic }\end{array}$} & Social Distancing & $0.000^{\mathrm{a}}$ & 0.23 & 0.123 & 0.496 \\
\hline & Washing hands & $0.185^{b}$ & - & 0.853 & 3.106 \\
\hline & Wearing a mask & $0.658^{c}$ & - & 0.394 & 1.616 \\
\hline & Strengthening the Body's Immune System & $0.307^{d}$ & - & 0.331 & 1.305 \\
\hline
\end{tabular}

a Significant result $(p<0.05) ; \mathrm{Cl}$, confidence interval; OR, odds ratio

infographics to describe the development of COVID-19 and to raise awareness of how people can participate to limit the spread of COVID (Figure 1 (ac)

The proportion of the population who still did activities outside the home more than 7 times in a week was $30.3 \%$, and the consistency in complying with the recommendations for preventing COVID-19 transmission was $20.5 \%$ (Table 1 ).

Table 2 shows the respondents who had understood the COVID-19 infographic (79.5\%), complied with Social Distancing recommendations (86.1\%) and the recommendation of washing hands as frequently as possible with soap and flowing water (74.3\%), tried to strengthen the body's immune system (73.6\%), and followed the recommendation of wearing a mask (50.9\%).

The percentages for the respondent's understanding of the infographics were as follows (Table 3): the meaning of the colors $(87.7 \%)$, the 
interpretation of the numerals (71.79\%), the understanding on the relevancy of information in the infographics $(41.02 \%)$, and the interpretation of regions at risk (69.65\%).

Referring to Table 4, most practices of social distancing have been done by the community to follow the government's recommendations. However, the rate for the habit of being in a crowd and doing unnecessary activities was still high (34.62\%) as well as meeting with elders and people with comorbidity $(54.71 \%)$

Results from the bivariate analysis are shown in Table 5 indicating a relationship between the understanding of COVID-19 infographics and practices of social distancing (OR $0.23, p=.000$ ).

\section{Discussion}

The control of a disease with a high rate of transmission, such as COVID-19, requires a comprehensive intervention. ${ }^{8,11,14}$ The WHO recommended avoiding community-level mobilization approaches that entail limiting large gatherings of people and use existing digital platforms for teleconsultations and to disseminate information and alert communities. ${ }^{15}$ Informing populations about the health risks posed by COVID-19, as well as measures they can take to protect themselves, is essential in mitigating the disease spreading and reducing the likelihood that people will become infected. ${ }^{16}$ The Samarinda Health Office provides and constantly updates information about COVID-19 and its spread, and has also recommended which health measures should be taken at the individual and collective levels in order to prevent COVID-19 infection and avoid further transmission. Because it is easily shared, infographics are an innovative and attractive method of visually communicating information in a colorful and concise way. ${ }^{17}$

The implementation of social distancing is the core component of the responses towards the COVID-19 pandemic. ${ }^{18,19}$ Several practices related to social distancing are aimed at reducing the probability of new infection by minimizing the physical contact between individuals. ${ }^{20}$ Even though the risk for the severity level of COVID-19 disease is different, each individual can possibly become infected and spread the virus. The provision of accurate, timely, and frequent information in a language that people understand enables populations to make better decisions, and adopt positive behaviors to protect themselves and their family from the COVID-19 pandemic. $^{21}$

In this study, it could be seen that a good understanding of COVID 19 infographics increased the willingness to comply with social distancing recommendations. Social distancing in some ways could decrease the COVID-19 transmission in the population of sub-groups by minimizing the physical contact between infected individuals and healthy individuals, or between the population group with a high transmission rate and the population group with the low transmission rate. ${ }^{18}$

The COVID-19 infographics provide information related to a mapping of the regions at risk. This information helps to make someone feel that there was a disease transmission near his/her domicile and try to keep a distance away from other people, especially the people they do not know. The risk of transmission after contact with an individual infected with COVID-19 increases with the closeness and duration of contact. ${ }^{22}$ Some epidemic experts agreed that small-scale social restrictions, such as in a neighborhood/village, have played an effective role in preventing the spread of disease in that area. ${ }^{14}$

Even though the local government of Samarinda did not implement the policy of large-scale social restrictions, the activities of the community outside their home experienced an extreme decline (Table 1). This illustration is in line with a survey conducted by East Kalimantan Community Mobility Report between April 4 - May 16, 2020, showing the increased number of the practice of staying at home $(15 \%)$, the decline in the activity at the workplace (22\%), the activity of shopping in the supermarket, pharmacy, and recreational activities (40\%). ${ }^{23}$ The enthusiasm of looking for information on COVID-19 infographics changes people's habit to be more solitary, careful, and compliant with the government's recommendations in the aspects of preventing COVID-19 transmission. The decrease of people's mobility along with keeping a safe distance and maintaining clean and healthy living behavior as 
well as wearing a mask have been proven effective to decrease new cases of COVID-19 infections. ${ }^{24}$

In this study, there were still people who did not keep a safe distance away from other people when going outside the home and were still gathering with others. The researchers thought that this behavior was mostly related to their occupation and the activities that are not relevant to the policy on physical distancing, such as traditional markets or shops/stalls managed by people. To minimize the transmission, people can perform their activities in a short time in those places and frequently wear a mask and wash their hands as soon as they go home. ${ }^{16}$

The distinct coordination and comprehensive implementation of social distancing at the initial phase of the outbreak was very effective to slow down the virus transmission. Even so, the implementation of social distancing in some regions considered the number of cases, the mortality rate, and social politics. ${ }^{19}$

A study in China illustrated that the virus can stay on surfaces for 6-8 hours. If someone touches the virus staying on the surface by accident and then touches his/her eyes, nose, and mouth, the virus will go directly to the lungs as the targeted organ. ${ }^{25}$ The rate of indirect transmission from hands contaminated with SARS Cov2 virus was very high. Cleaning objects that are often touched by people at home or in public places using antiseptic regularly will reduce the chance for the virus to stay longer on the surface..$^{25,26}$

This study showed that a good understanding of infographics did not significantly influence the recommendation of washing hands using soap. In this study, it was shown that not all respondents did the recommendation to wash hands due to their physical and economic limitations and the low availability of clean water supply outside the home. Hands that are contaminated with the virus may transfer the virus to the face. Mouth and eyes unwittingly become the port de entry for the virus transmission. ${ }^{27}$ The consistency of washing hands was not seen yet due to the frequency of people's activity outside the home. Therefore, most people appear to be bored by washing hands repeatedly. The unwillingness to wash hands frequently and safeguard themselves by washing hands at home can increase the potential of virus transmission. The practice of washing hands effectively with soap can kill bacteria or viruses; moreover, always keeping our hands dry is a part of effective handwashing practice. Research has shown that the practice of washing hands 6 to 10 times in a day can decrease the risk of being infected with COVID-19.28

Masks are simple, cheap and potentially effective safeguards against COVID-19 transmission. ${ }^{29}$ There is evidence that wearing a mask by individuals in the households or during contacts with a sick patient, or among attendees of a mass gathering is particularly beneficial as a preventive measure against infection. ${ }^{30,31}$ A study on influenza illustrated that wearing a surgical mask could prevent the spread of the droplets that cause infection and possible virus contamination in the surrounding area. ${ }^{27}$ The feeling of being safe if wearing a mask is pseudo-safety if people do not comply with other preventive actions, such as washing hands and physical distancing because people still can touch their face behind the mask and their eyes. ${ }^{30,32}$

This study showed that a good understanding of the infographics did not significantly influence the practice of wearing a mask. This finding might be caused by the increasing level of assumption in the community that there are no COVID-19 cases anymore in Samarinda. Some reasons to explain not wearing masks by people were feeling uncomfortable, feeling that it is impossible to be infected, having no mask, and wearing a mask only when meeting unknown people outside the home. Also, wearing a mask is considered as impolite when talking, especially with people they already know. Even so, the consistency of wearing a mask in this study was still relatively high ( $>50 \%)$. People also feel protected from both air pollution and COVID-19 when wearing a mask.

Keeping the body's immune system strong is an important method in preventing viral infection and disease transmission. Clean and healthy living behavior such as getting enough rest, consuming balanced nutritious food, managing stress, doing exercises, and avoiding cigarette smoke, can strengthen the body's immune system. ${ }^{8,33,34}$. Some 
studies illustrated that sunlight exposure in the morning could stimulate the production of vitamin $D$ that plays a role in absorbing calcium and phosphorous. ${ }^{35,36}$ Besides, vitamin $\mathrm{D}$ also functions to reduce the overactive immune system, so the amount of white blood cells increases and it can prevent the coronavirus from entering the body. This study showed that a good understanding of infographics did not significantly influence the recommendation of keeping the body's immune system strong during the COVID-19 pandemic.

We argued that some people who live in high incidence areas do not consider themselves at risk, underestimate the seriousness of the condition and may not see themselves as capable to perform the preventive behaviors. Changing people's behavior is simply not as easy as just informing them of the risks. ${ }^{37}$ Misinformation related to COVID-19 can potentially contribute to more severe health problems, ongoing transmission, and difficulties controlling the disease outbreak. Lack of access to technology or good Internet connectivity is also an obstacle to continue seeing the infographics, especially for people from rural areas or disadvantaged families. ${ }^{17}$ One of the weaknesses of this study was that we only measured the understanding of infographics as the dependent factor, even though people were getting information and education about prevention of COVID-19 transmission from other sources not only from the infographics. Secondly, the levels of knowledge and the actions related to the protocol of preventing disease transmission were measured based on the respondents' perceptions and responses to the survey, not real observed actions.

\section{Conclusion}

We believe that increasing understanding of infographics concerning COVID-19 will increase efforts to improve adherence to the recommendations for social distancing. The implementation of social distancing, wearing a mask, washing hands as frequently as possible, and the efforts to take care of the body's immune system need to be done consistently to prevent the COVID-19 infection and the potential transmission could be minimized to optimize the recovery phase and anticipate the possible second wave of COVID-19. The protocols of preventing disease transmission will need to be maintained until an effective and safe vaccine becomes available.

\section{Conflict of interests}

The authors stated that all of them have no conflict of interests in this paper.

\section{Acknowledgement}

The authors would express gratitude to the Dean of Faculty of Medicine, Universitas Mulawarman, and the Director of Poltekkes Kalimantan Timur who gave the authors permission to conduct the study and to the head of the Health Office of Samarinda City and the COVID-19 control team who gave access and data clarification in the COVID-19 Infographics.

\section{References}

1. Kemenkes, PHEOC. Situasi terkini perkembangan coronavirus disease (COVID-19) [Internet]. 2020. Available from: https://covid19.kemkes.go.id/ situasi-infeksi-emerging/info-corona-virus/ situasi-terkini-perkembangan-coronavirusdisease-covid-19-5-mei-2020/\#.XreWOlUzbIU

2. WHO. Coronavirus disease (COVID-2019) situation reports [Internet]. 2020. Available from: https://www.who.int/emergencies/ diseases/novel-coronavirus-2019/situationreports

3. WHO. Coronavirus disease (COVID-19) situation report- 120 [Internet]. 2020. Available from: https://www.who.int/docs/default-source/ coronaviruse/situation-reports/20200519covid-19-sitrep-120.pdf?sfvrsn=515cabfb_2

4. Gugus Tugas Percepatan Penanganan COVID-19. Infografis COVID-19 [Internet]. 2020. Available from: https://covid19.go.id/p/berita/infografiscovid-19-21-april-2020

5. Pemerintah Provinsi Kalimantan Timur. Laporan COVID-19 Kalimantan Timur [Internet]. 2020. Available from: https://covid19.kaltimprov. go.id/laporan

6. Osa Rafshodia. Analisa epidemiologi dan rekomendasi mitigasi COVID-19 Kota Samarinda. 2020. 
7. Sifriyani. Prediksi puncak dan berakhir kasus positif COVID-19 di Kalimantan Timur. Samarinda; 2020.

8. WHO. Report of the WHO-China joint mission on coronavirus disease 2019 (COVID-19) [Internet]. 2020. Available from: https://www.who.int/ docs/default-source/coronaviruse/who-chinajoint-mission-on-covid-19-final-report.pdf

9. WHO, UNICEF, IFRC. Pesan dan kegiatan utama pencegahan dan pengendalian COVID-19 di sekolah. 2020.

10. Indonesian Ministry of Health 2020b. Prevent COVID-19 with Germas (Jakarta).

11. Indonesia Ministry of Health. National Health Care Guideline for Coronavirus 2019 (COVID-19) in Indonesia (Jakarta). 2020a.

12. Sukmana $M$, Aminuddin $M$, Nopriyanto $D$. Indonesian government response in COVID-19 disaster prevention. East African Sch J Med Sci. 2020;3(3):81-6.

13. Samarinda DK. Perkembangan dan persiapan memasuki fase relaksasi tahap I COVID-19. 2020.

14. IFRC, UNICEF, WHO. COVID-19 preparedness \& response [Internet]. 2020. Available from: https://www.unicef.org/media/65936/file/ Preparedness for and response to Coronavirus 2019 (COVID-19).pdf

15. IFRC, UNICEF, WHO. COVID-19 preparedness \& response [Internet]. 2020. Available from: https://www.who.int/publications/i/item/riskcommunication-and-community-engagement(rcce)-action-plan-guidance

16. UNICEF, WHO, IFRC. Key messages and actions for COVID-19 prevention and control in schools. 2020.

17. Siricharoen W V. Infographic role in helping communication for promoting health and well-being. 2015. Available from:https://www. researchgate.net/publication/282276574

18. Matrajt L, Leung $T$ any. Evaluating the efectiveness of social distancing interventions against COVID-19. Emerg Infect Dis. 2020;26(8).

19. Stephen K, Christine T, Lipsitch M, Grad $\mathrm{YH}$. Social distancing strategies for curbing the COVID-19 epidemic. medRxiv. Available from: https://www.medrxiv.org/ content/10.1101/2020.03.22.20041079v1.full. pdf + html

20. Singer RAJ. The math behind social distancing [Internet]. 2015. Available from: https:// globalnews.ca/news/6709071/coronavirussocial-distancing-math/

21. Li W, Liao J, Li Q. Health education for parents during the COVID-19 outbreak public health education for parents during the outbreak of COVID-19: a Rapid Review. medRxiv Prepr. 2020; preprint.

22. Hao-Yuan Cheng, MD Ms, Shu-Wan Jian, DVM, MPH Ding-Ping Liu P, Ta-Chou Ng Bs, Wan-Ting Huang $M$, Hsien-Ho Lin, MD S. Contact tracing assessment of COVID-19 transmission dynamics in Taiwan and risk at different exposure periods before and after symptom onset. JAMA Intern Med. 2020;1(May):E1-8.

23. Google. Survey Indonesia Community Mobility Report [Internet]. 2020. Available from: https:// www.google.com/covid19/mobility/

24. Suppawittaya P, Yiemphat P, Yasri P. Effects of social distancing, self-quarantine and selfisolation during the COVID-19 pandemic on people's well-being, and how to cope with it. Int J Sci Healthc Res. 2020; 5(2).

25. Warnes SL, Zoë R. Little C, Keevil W. Human coronavirus 229e remains infectious on common touch surface materials. MBio. 2015;6(6):e01697-15.

26. WHO. Interim recommendations on obligatory hand hygiene against transmission of COVID-19 [Internet]. Available from: https://www. who.int/who-documents-detail/interimrecommendations-on-obligatory-hand-hygieneagainst-transmission-of-COVID-19

27. Aiello AE, Murray GF, Perez V, Coulborn RM, Davis $\mathrm{BM}$, Uddin $\mathrm{M}$, et al. Mask use, hand hygiene, and seasonal influenza- like illness among young adults: a randomized intervention trial. $J$ Infect Dis. 2010;201:491-8.

28. Hunt J, Gammon J. Coronavirus and handwashing: research shows proper hand drying is also vital. Cited June,11 2020. Available from: https://theconversation.com/coronavirusand-handwashing-research-shows-properhand-drying-is-also-vital-132905 
29. Greenhalgh T, Schmid MB, Czypionka T, Bassler $D$, Gruer L. Face masks for the public during the COVID-19 crisis. BMJ. 2020;369(m1435):1-4.

30. Howard J, Huang A, Li Z, Tufekci Z, Zdimal V, Westhuizen $\mathrm{H}-\mathrm{M}$ van der, et al. Face masks against COVID-19: an evidence review. Prepr. 2020;1-8. Available from: doi: 10.20944/ preprints202004.0203.v1

31. Howard J, Huang A, Lik Z, Tufekci Z, Zdimal V, Westhuizenf $\mathrm{H}-\mathrm{M}$ van der, et al. Face masks against COVID-19: an evidence review. Preprint. 2020;1-8.

32. Coia JE, Ritchie L, Adisesh A, Booth CM, Bradley C, Bunyan $D$, etal. Guidance on the use of respiratory and facial protection equipment. J Hosp Infect [Internet]. 2013;(85). Available from: https:// www.journalofhospitalinfection.com/action/ showPdf?pii=S0195-6701\%2813\%2900279-X
33. Guidelines for the use of non-pharmaceutical measures to delay and mitigate the impact of 2019-nCoV [Internet]. 2020. Available from: https://www.ecdc.europa.eu/en/publicationsdata/guidelines-use-non-pharmaceuticalmeasures-delay-and-mitigate-impact-2019-ncov

34. Hemilä $\mathrm{H}$, Chalker E. Vitamin C for preventing and treating the common cold. Cochrane Database Syst Rev. 2013;(1).

35. Asyary A, Veruswati M. Sunlight exposure increased COVID-19 recovery rates: a study in the central pandemic area of Indonesia. Sci Total Environ. 2020;729:1-4.

36. Board INE. Indonesia is high potential to sunlight beneficiary[WWW Document]. 2013.

37. Broucke $S$ Van den. Why health promotion matters to the COVID-19 pandemic, and vice versa. Health Promot Int. 2020;35:181-6. 